\title{
Analisis Transformator Sisipan Dengan Simulasi Program ETAP Pada Penyulang Cp15 PT. PLN (Persero) ULP Banjarbaru
}

\author{
Feri Rahman ${ }^{1}$ \\ ${ }^{1}$ Program Studi Teknik Elektro, Universitas Islam Kalimantan M A B \\ Rahman1704@gmail.com
}

A

bstrak - Transformator adalah salah satu bagian penting dalam teknologi konversi energi listrik salah satunya di sisi tegangan dan daya listrik. Di PLN khususnya di sisi transmisi dan distribusi transformator yang digunakan yaitu jenis step down (menurunkan tegangan) dimana di sisi transmisi misalkan tegangan pada TT (Tegangan Tinggi) $150 \mathrm{kV}$ diturunkan menjadi tegangan TM (Tegangan Menengah) $20 \mathrm{kV}$ kemudian diturunkan lagi menjadi TR (Tegangan Rendah) $400 \mathrm{~V}$. Seiring dengan perkembangan teknologi dan meningkatnya kebutuhan masyarakat akan energi listrik baik diperkotaan hingga di pedesaan. PLN sebagai instansi pemerintah yang ditunjuk sebegai pengelola kelistrikan bertanggung jawab atas kualitas pelayanan kelistrikan baik itu eksisting maupun perluasan pelayanan kelistrikan. Sehingga untuk kondisi peralatan terpasang salah satunya transformator sangat perlu diperhatikan guna menghindari terjadinya keruskan akibat kelebihan beban baik itu karena overload atau overblast apakah itu preventif berupa penggantian trafo atau dengan melakukan pemasangan transformator sisipan.

Berkaitan dengan perihal hal tersebut di atas di sini saya mencoba untuk menganalisis rencana pemasangan transformator sisipan menggunakan Output Data hasil ETAP (Electric Transient and Analysis Program) guna mencegah terjadinya kerusakan tranformator akibat beban overload dan overblast.

Kata Kunci : Transformator, Overload, Overblast, Transformator sisipan, ETAP

\section{PENDAHULUAN}

Di PLN ULP Banjarbaru khususnya untuk rencana proses pemasangan transformator sisipan hanya berdasarkan pada data teknik transformator tanpa memperhitungkan apakah penempatan itu sudah ideal atau tidak terhadap dampak teknik yang ditimbulkan seperti kualitas tegangan dan losses (energi yang hilang). Oleh sebab itu di sini penulis mencoba analisis pemasangan transformator distribusi $20 \mathrm{kV}$ sisipan pada Penyulang CP15 di PT PLN (Persero) ULP Banjarbaru dengan menggunakan ETAP dengan tujuan mendapatkan data Kajian Kelayakan Operasional maupun Finansial.

\section{METODE PENELITIAN}

Pada tahapan ini meliputi penentuan apa saya yang perlu disiapkan untuk memulai kegiatan diantaranya :

1. Menentukan alat, program dan data yang akan diperlukan untuk proses analisis;

2. Menentukan Narasumber yang diperlukan; dan

3. Menentukan jadwal atau planning penelitian yang akan dilaksanakan

\section{Pengumpulan Data Existing}

Pengumpulan Data yang dimaksud adalah mencari data awal sebelum pelaksanaan transformator sisipan dilakukan. Data yang diperlukan diantaranya :

1. Single Line Diagram (SLD) Jaringan sistem distribusi khususnya penyulang CP15 dengan narasumber dari PLN ULP Banjarbaru dan PLN APD Kalselteng;

2. Daftar transformator distribusi (Kapasitas Transformator, beban / arus, Tegangan) dengan narasumber dari PLN ULP Banjarbaru ;

3. Daftar transformator rencana sisipan dengan narasumber dari PLN ULP Banjarbaru; dan 
4. Data penghantar terpasang pada penyulang (Jenis penghantar dan panjang penghantar persection)

Pada proses pengumpulan data khususnya pada point 4 yaitu data penghantar terpasang di PLN ULP Banjarbaru belum ada. Maka diperlukan adanya survei kelapangan perihal keperluan data tersebut.

\section{Survei ke Lapangan}

Menindaklanjuti keperluan data penghantar terpasang pada Penyulang CP15, untuk pelaksanaan survei dilapangan diawali dengan koordinasi dengan PLN ULP Banjarbaru dan PLN APD Banjarbaru. Adapun koordinasi tersebut diperlukan untuk memastikan bahwa penyulang yang akan disurvei benar-benar penyulang CP15 bukan penyulang yang lain. Hal itu dikarenakan ada 4 (empat) penyulang arah bati-bati yang tersupply dari GI Cempaka.

Proses survei juga dilakukan pada transformator yang sebelumnya terindikasi sudah dalam kondisi overload yaitu pada :

\section{Transformator No.G.236 (Cempaka Hulu) dengan kapasitas $160 \mathrm{kVA}$ dan beban $166 \mathrm{kVA}(103 \%)$ \\ 2. Transformator No.G.887 (BTS arah ke} Penjara Bangkal) dengan kapasitas 160 kVA dan beban $152 \mathrm{kVA}(95 \%)$

Proses survei juga dilakukan pada transformator yang sudah terpasang dengan yaitu :
1. Transformator Sisipan (Sisipan Cempaka Hulu) dengan kapasitas 100 kVA.
2. Transformator Sisipan (Sisipan arah ke Penjara Bangkal) dengan kapasitas 100 kVA

\section{DATA HASIL PENELITIAN DAN PEMBAHASAN}

Setelah proses pendataan dan input data kedalam program ETAP sudah berjalan, maka ada dua versi ETAP yang akan dibuat yaitu SLD ETAP kondisi sebelum pemasangan trafo sisipan pada gambar 1 serta nilai losses nya pada gambar 2 dan Kondisi setelah trafo sisipan terpasang. Berikut proses pelaksanaan analisa dengan menggunakan ETAP.

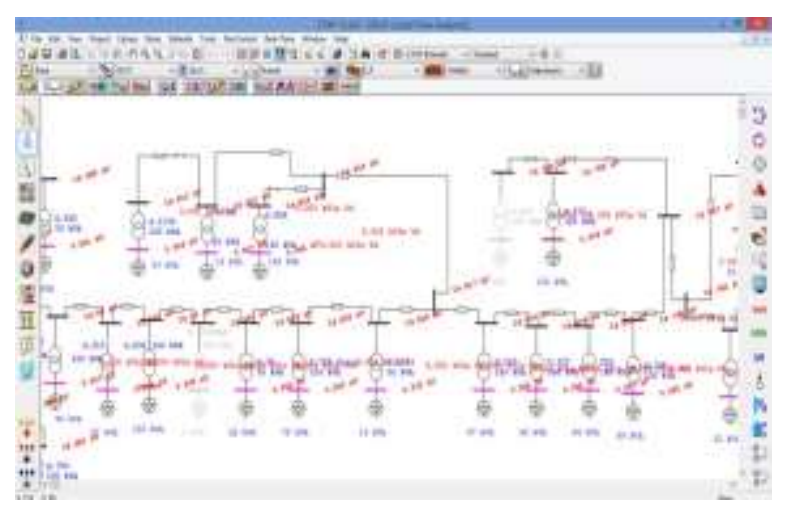

Gambar 1. Hasil ETAP Sebelum dipasang Transformator Sisipan

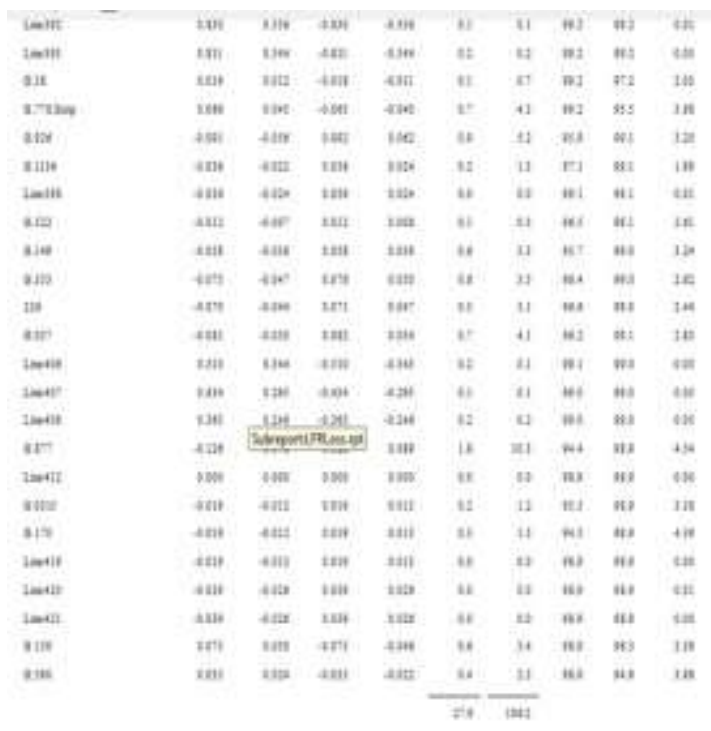

Gambar 2. Nilai Losses Sebelum dipasang Transformator Sisipan

Dari keterangan gambar $1 \& 2$ maka nilai losses yang didapat yaitu 27,9 KW adapun untuk kondisi sesudah pemasangan transformator sisipan ditunjukan pada gambar 3 dan losses nya pada gambar 4 


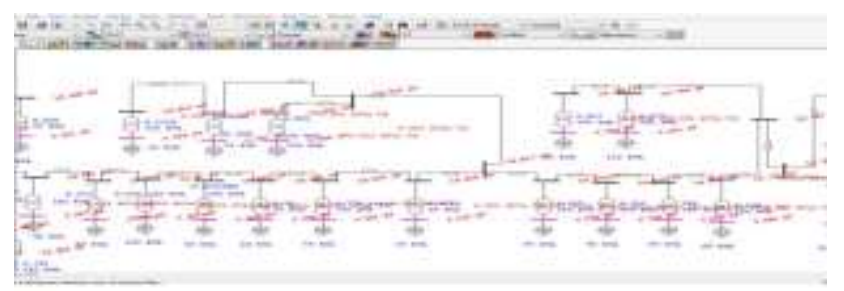

Gambar 3. Hasil ETAP Setelah dipasang Transformator Sisipan

\begin{tabular}{|c|c|c|c|c|c|}
\hline 0.522 & $-0,012$ & -0.007 & 0.012 & 0.008 & 0.1 \\
\hline G.149 & -0.058 & -0.036 & 0.058 & 0.039 & 0.6 \\
\hline G. 353 & -0.075 & -0.047 & 0.076 & 0.050 & 0.6 \\
\hline 226 & -0.070 & -0.044 & 0.071 & 0.047 & 0.5 \\
\hline G.057 & -0.081 & -0.050 & 0.082 & 0.034 & 0.7 \\
\hline Line 406 & 0.511 & 0.340 & .0 .510 & -0.340 & 0.2 \\
\hline Line 407 & 0.434 & 0.290 & -0.434 & -0.290 & 0.1 \\
\hline Lise 408 & 0.363 & 0.243 & -0.363 & -0.243 & 0.2 \\
\hline 0.877 & $-0,094$ & -0.058 & 0.095 & 0.064 & 1.0 \\
\hline G.807 & -0.034 & -0.021 & 0.034 & 0.022 & 0.2 \\
\hline Line 412 & -0.034 & -0.022 & 0.034 & 0.022 & 0.0 \\
\hline 0.0315 & -0.019 & -0.012 & 0.019 & 0.013 & 0.2 \\
\hline 0.170 & -0.019 & -0.012 & 0.019 & 0.013 & 0.3 \\
\hline Lise 419 & -0.019 & -0.013 & 0.019 & 0.013 & 0.0 \\
\hline Litise 420 & -0.039 & $\cdot 0.026$ & 0.039 & 0.026 & 0.0 \\
\hline Line 421 & -0.039 & -0.026 & 0.039 & 0.026 & 0.0 \\
\hline G.150 & 0.075 & 0.050 & -0.075 & -0.046 & 0.6 \\
\hline G.590 & 0.035 & 0.024 & -0.035 & -0.022 & 0.4 \\
\hline
\end{tabular}

Gambar 4. Nilai losses Setelah dipasang transformator sisipan

Dari keterangan gambar $3 \& 4$ maka nilai losses yang didapat yaitu 26,4 KW

Dari kegiatan analisa diatas maka dapat dilihat perubahan nilai teknik setelah pemasangan tarnsformator sisipan dilaksanakan yaitu sebagai berikut :

1. Adanya kenaikan tegangan pegangan khususnya pada transformator yang sebelumnya overload yaitu:

a. Gardu 877 dari tegangan sebelumnya $359 \mathrm{~V}$ menjadi $369 \mathrm{~V}$

b. Gardu 236 dari tegangan sebelumnya $359 \mathrm{~V}$ menjadi $369 \mathrm{~V}$

2. Adanya penurunan nilai losses yang sebelumnya $27,9 \mathrm{~kW}$ menjadi $26,4 \mathrm{~kW}$ atau selisih sebesar 1,5 kW.

Selain perbaikan nilai ternik kegiatan pemasangan transformator sisipan juga menghasilan saving dan gain.
1. Saving.

Saving adalah nilai yang diselamatkan yang selama ini hilang atau tidak terhitung akibat kondisi teknik yang menyebabkan rugi-rugi khususnya pada nilai losses.

Nilai losses yang didapat yaitu :

Losses Sebelum = $27,9 \mathrm{~kW}$

Losses Sesudah $\quad=26,5 \mathrm{~kW}$

Maka nilai selama 1 (satu) bulan dengan asumsi koefisien beban berdasar sifat pembebanan dominasi pelanggan umum yaitu 0,8 maka :

- Susut Sebelum x Jam Nyala x 0,8 :

$$
\begin{aligned}
& =27,9 \times 720 \times 0,8 \\
& =16.070,4 \mathrm{kWh}
\end{aligned}
$$

- $\quad$ Susut Sesudah x Jam Nyala x 0,8 :

$$
\begin{aligned}
& =26,5 \times 720 \times 0,8 \\
& =15.264 \mathrm{kWh}
\end{aligned}
$$

- Selisih $=$ Susut Sebelum-Susut Sesudah

$$
=16.070,4-15.264
$$

$$
=806,4 \mathrm{kWh}
$$

Apabila dikalikan dengan Rupiah per kWh sebesar 1.467,28 (Pelanggan Daya 1300 VA), maka:

Saving di dapat sebesar :

Selisih kWh x Rp/kWh

$$
\begin{aligned}
& =806,4 \times 1.467,28 \\
& =\text { Rp. 1.183.214,592,- }
\end{aligned}
$$

2. Gain.

$\begin{array}{ccc}\text { Sedangkan untuk nilai gain } \\ \text { adalah } & \text { tambahan } & \text { kemampuan }\end{array}$ Transformator untuk melayani kebutuhan pelanggan dikarenakan pengurangan beban yang dimanuver/dipindahkan sebagian ke transformator sisipan seperti tambah daya dan sambung baru. Misalkan pada calon pelanggan Sambung Baru dengan permintaan sebesar 1300 VA maka gain yang didapat selama 1 (satu) bulan apabila permintaan tersebut dipenuhi yaitu sebesar : $=(80 \%$ pemakaian perhari dari daya terpasang) $x$ Rp/kWh x Jam Nyala) 
$=(0,8 \times(1.300 \times 0,85)) \times 1.467,28 \times 720$

$=$ Rp. 700.420,8 per Pelanggan Perbulan.

\section{KESIMPULAN}

1. Penggunaan ETAP pada proses analisa pemasangan transformator sisipan sangat membantu dalam membuat justifikasi rencana pemasangan transformator sisipan.

2. Pemasangan transformator sisipan sangat berpengaruh terhadap kondisi beban, tegangan dan losses yang dihasilkan.

3. Pemasangan transormator sisipan selain memberikan nilai saving juga memberikan nilai gain dikarenakan bertambahnya kapasitas transformator.

4. Meningkatnya kualitas pelayanan distribusi juga dapat meningkatkan citra pelayanan PLN terhadap pelanggan dan calon pelanggan baik dari segi kualitas tegangan pelayanan maupun penambahan daya dan jumlah pelanggan.

\section{DAFTAR PUSTAKA}

Ari Amrinal Putra (2014). ETAP (Electrical Transient Analyzer Program) Power Station Retrieved from http://duniaelectrical.blogspot.com/2014/12/tentan g-etap-electrical-transient.html

Muhammad Setia Budi Luhur (2015). Perencanaan Pemasangan Transformator Sisipan Gardu Distribusi I Dengan Menggunakan Etap 12.6 ,
Retrieved from http://eprints.polsri.ac.id/1730/

I Putu Sutawinaya, I Wayan Teresna dan Febry Setyacahyana P. (2014). Studi Analisis Penambahan Transformator Sisipan Untuk Menopang Beban Lebih Dan Drop Tegangan Pada

Transformator Distribusi Ka 1516 Penyulang Buduk Menggunakan Simulasi Program Etap 7.0.

Retrieved from http://www.academia.edu/

Daman Suswanto, Sistem Distribusi Tenaga Listrik. Hal. 147, 2009)

Kelompok Kerja Standar Kontruksi Distribusi Jaringan Tenaga Listrik dan Pusat Penelitian Sains dan Teknologi Universitas Indonesia. Standar Konstruksi Gardu Distribusi dan Gardu Hubung Jaringan Distribusi Tenaga Listrik, , 2010 )

Modul Praktikum Sistem Tenaga II, Laboratorium Sistem Tenaga Listrik Program Studi Teknik Elektro Fakultas Teknik, UNTAG. 2016

Lesnanto Multa P, S.T., M.Eng,. Modul Pelatihan ETAP. 2013

Kapahi .R., (2013).Load Flow Analysis of 132 $\mathrm{kV}$ substation using ETAP Software, \& Technology under Punjab Technical University, India., Volume 4 